\title{
Comparative Study of Helminth Parasites of the Many-Ribbed Salamander, Eurycea multiplicata and Oklahoma Salamander, Eurycea tynerensis (Caudata: Plethodontidae), from Arkansas and Oklahoma, A
}

C. T. McAllister

Eastern Oklahoma State College, cmcallister@se.edu

M. B. Connior

South Arkansas Community College

C. R. Bursey

Pennsylvania State University

H. W. Robison

Follow this and additional works at: https://scholarworks.uark.edu/jaas

Part of the Animal Diseases Commons, and the Other Animal Sciences Commons

\section{Recommended Citation}

McAllister, C. T.; Connior, M. B.; Bursey, C. R.; and Robison, H. W. (2014) "Comparative Study of Helminth Parasites of the Many-Ribbed Salamander, Eurycea multiplicata and Oklahoma Salamander, Eurycea tynerensis (Caudata: Plethodontidae), from Arkansas and Oklahoma, A," Journal of the Arkansas Academy of Science: Vol. 68 , Article 15.

DOI: https://doi.org/10.54119/jaas.2014.6810

Available at: https://scholarworks.uark.edu/jaas/vol68/iss1/15

This article is available for use under the Creative Commons license: Attribution-NoDerivatives 4.0 International (CC BY-ND 4.0). Users are able to read, download, copy, print, distribute, search, link to the full texts of these articles, or use them for any other lawful purpose, without asking prior permission from the publisher or the author. This Article is brought to you for free and open access by ScholarWorks@UARK. It has been accepted for inclusion in Journal of the Arkansas Academy of Science by an authorized editor of ScholarWorks@UARK. For more information, please contact scholar@uark.edu. 


\title{
A Comparative Study of Helminth Parasites of the Many-Ribbed Salamander, Eurycea multiplicata and Oklahoma Salamander, Eurycea tynerensis (Caudata: Plethodontidae), from Arkansas and Oklahoma
}

\author{
C.T. McAllister ${ }^{*}$, M.B. Connior ${ }^{2}$, C.R. Bursey ${ }^{3}$, and H.W. Robison ${ }^{4}$ \\ ${ }^{1}$ Division of Science and Mathematics, Eastern Oklahoma State College, Idabel, OK 74745 \\ ${ }^{2}$ Health and Natural Sciences, South Arkansas Community College, El Dorado, AR 71730 \\ 3Department of Biology, Pennsylvania State University, Shenango Campus, Sharon, PA 16146 \\ ${ }^{4} 9717$ Wild Mountain Drive, Sherwood, AR 72120
}

*Correspondence: cmcallister@se.edu

Running Head: Helminths of Eurycea spp.

\begin{abstract}
Ninety many-ribbed salamanders, Eurycea multiplicata and 135 Oklahoma salamanders, Eurycea tynerensis were collected between April 2010 and April 2014 from 14 counties of Arkansas and McCurtain County, Oklahoma (E. multiplicata only) and examined for helminth parasites. Twelve (13\%) $E$. multiplicata were infected, including two (2\%) each with Brachycoelium salamandrae, Bothriocephalus rarus, Batracholandros magnavulvaris, Cosmocercoides variabilis, and Omeia papillocauda, and one $(1 \%)$ each with an oligacanthorhynchid cystacanth and Fessisentis vancleavei. Forty-one (30\%) of the E. tynerensis were infected, including seven (5\%) with Gorgoderina tenua, two (1\%) each with Phyllodistomum solidum and cyclophyllidean tapeworm cysticerci, one $(0.7 \%)$ with Cylindrotaenia americana, six (3\%) with B. rarus, eight (12\%) with Desmognathinema nantahalaensis, 10 (7\%) with $O$. papillocauda, two (1\%) with Amphibiocapillaria tritonipunctata and six (4\%) with $F$. vancleavei. We document 13 new host and two new distributional records for helminths of these salamanders. In addition, a summary of the endoparasites of $E$. multiplicata and E. tynerensis is provided.
\end{abstract}

\section{Introduction}

The many-ribbed salamander, Eurycea multiplicata ranges south of the Arkansas River and throughout the Ouachita Mountains of west-central Arkansas and adjacent southeastern Oklahoma (Trauth et al. 2004, Sievert and Sievert 2011). It is a metamorphic surface-dwelling plethodontid that frequents aquatic sites including abandoned mine shafts and spring seeps and can also be found under damp rocks and logs in deciduous forest. Although much has been published on the ecology of $E$. multiplicata (Dundee 1965, Trauth and Dundee 2005), little is published about its helminth parasites. McAllister and Bursey (2010) examined 66 E. multiplicata from Arkansas and Oklahoma and reported three species of nematodes.

The Oklahoma salamander, Eurycea tynerensis (Ozark gray-belly salamanders, Eurycea multiplicata griseogaster Moore and Hughes $1941=$ E. tynerensis [sensu Bonett and Chippendale 2004]) ranges north of the Arkansas River in the state throughout the Ozark Highlands and westward to northeastern Oklahoma where it is found in cool springs, spring-fed creeks with cherty gravel bottoms and cave streams (Trauth et al. 2004). Likewise, a great deal has been published on the biology of this salamander (Dundee 1965, Ireland 1976, Cline et al. 1989, 1997, 2001, Tumlison et al. 1990a, b, Tumlison and Cline 2003, Bonett 2005, Emel and Bonett 2011, Martin et al. 2012, Connior et al. 2014) but less is available on its helminths. However, most studies are of a fragmentary nature including: Hughes and Moore (1943a,b) who described an acanthocephalan (Fessisentis vancleavei) and a monogenean (Sphyranura euryceae) from E. tynerensis from Cherokee County, Oklahoma; Malewitz (1956) reported $F$. vancleavei from specimens from Cherokee County; Buckner and Nickol (1978) provided a redescription of Fessisentis vancleavei (Acanthocephala) from E. tynerensis from Oklahoma; McAllister et al. (1991) reported $S$. euryceae from $E$. tynerensis from Arkansas; Bonett et al. (2011) reported on Clinostomum marginatum in E. tynerensis from Oklahoma; and McAllister et al. (2011) provided a study of $S$. euryceae from E. tynerensis from northeastern Oklahoma. In the most thorough survey to date, McAllister et al. (1995b) reported trematode, 
Journal of the Arkansas A cademy of Science, V ol. 68 [2014], Art. 15

nematode, and acanthocephalan parasites from $E$. tynerensis $(=E . m$. griseogaster) from seven counties of the Arkansas River Valley. There have also been several unpublished theses on parasites of this salamander from Arkansas and Oklahoma, and while not mentioned specifically herein, they are referenced in McAllister et al. (1995b, 2011).

Here, we provide 13 new host and two new distribution records for some helminth parasites of $E$. multiplicata and E. tynerensis. In addition, a summary of their endoparasites is reported.

\section{Materials and Methods}

Between April 2010 and April 2014, 90 larval and adult $E$. multiplicata (mean \pm snout-vent length [SVL] $=35.2 \pm 6.6,19-48 \mathrm{~mm}$ ) were collected by hand or aquatic dip-net from (sample sizes in parentheses) Clark (4), Conway (21), Garland (1), Montgomery (21), Polk (1) and Saline (40) counties, Arkansas, and McCurtain (2) County, Oklahoma; 135 larval, paedomorphic and adult E. tynerensis $([\mathrm{SVL}]=41.5 \pm$ $5.3,23-53 \mathrm{~mm}$ ) were collected in the same manner from Benton (3), Carroll (5), Cleburne (8), Franklin (5), Johnson (9), Marion (36), Searcy (68) and Washington (1) counties (Fig. 1).

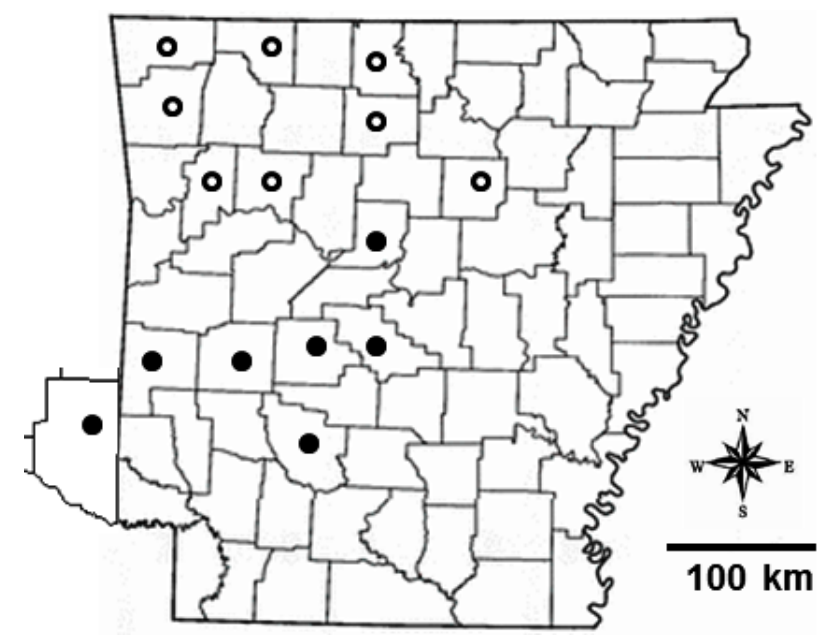

Figure 1. Arkansas and se corner of Oklahoma. Solid dots mark counties where Eurycea multiplicata were collected on the Ouachita Plateau/Arkansas River Valley; open dots mark counties where Eurycea tynerensis were collected on the Ozark Plateau.

Specimens were placed in habitat water on ice and taken to the laboratory for necropsy. Salamanders were killed by prolonged immersion in a dilute chloretone ${ }^{\circledR}$ (chlorobutanol) solution. If gills were present, they were examined for monogeneans under a stereomicroscope. A mid-ventral incision was made to expose the viscera and the entire gastrointestinal tract, liver, gall bladder, spleen, urinary bladder and gonads were examined for helminths. Trematodes and cestodes were stained with acetocarmine and mounted in Canada balsam, and nematodes and acanthocephalans were placed on a glass slide in a drop of undiluted glycerol for identification. Prevalence, mean intensity, and range of infection are provided and are in accordance with terminology given in Bush et al. (1997). Helminth voucher specimens were deposited in the United States National Parasite Collection (USNPC), Beltsville, Maryland. Host voucher specimens were deposited in the Arkansas State University Museum of Zoology, Herpetological Collection (ASUMZ) as ASUMZ 32605-32611 and 32616.

\section{Results and Discussion}

We found 13 helminths, including three trematodes, three cestodes, five nematodes, and two acanthocephalans. Six helminths were found in $E$. multiplicata and 10 helminths were harbored by $E$. tynerensis; four helminths were shared by both species. Twelve (13\%) of the E. multiplicata and $41(30 \%)$ of the E. tynerensis harbored at least one helminth. A detailed annotated list of the helminths recovered from E. multiplicata and E. tynerensis is presented below, with a Table summarizing all helminths reported from these two hosts.

\section{Digenea: Brachycoeliidae}

\section{TREMATODA}

Brachycoelium cf. salamandrae (Frölich, 1789) Dujardin, 1845. - We tentatively document $B$. salamandrae (Fig. 2) in three (3\%) E. multiplicata. A larval specimen ( $35 \mathrm{~mm} \mathrm{SVL}$ ) from Cox Spring off St. Hwy. 8, Montgomery County $\left(34.456421^{\circ} \mathrm{N}\right.$, $\left.93.845254^{\circ} \mathrm{W}\right)$ had six worms and two adults $(34,38$ $\mathrm{mm}$ SVL) from Shannon Hills, Saline County $\left(34.60996^{\circ} \mathrm{N}, 92.43227^{\circ} \mathrm{W}\right)$ possessed two and three worms in their small intestine, respectively. McAllister et al. (1995) reported B. salamandrae from E. tynerensis from Conway County. Other hosts from Arkansas include six salamanders, four frogs/toads and a skink (McAllister 2013c, 2014). Interestingly, McAllister et al. (2014) recently noted they had serious doubts about Old World and New World $B$. salamandrae being conspecific (see summary by Bursey et al. 2012), and suggested caution with their former conclusions (McAllister et al. 2013d) and until a molecular approach was completed (V.V. Tkach,

\section{Journal of the Arkansas Academy of Science, Vol. 68, 2014}


pers. comm.). However, regardless what species is eventually verified, this is a new host record for the genus Brachycoelium.

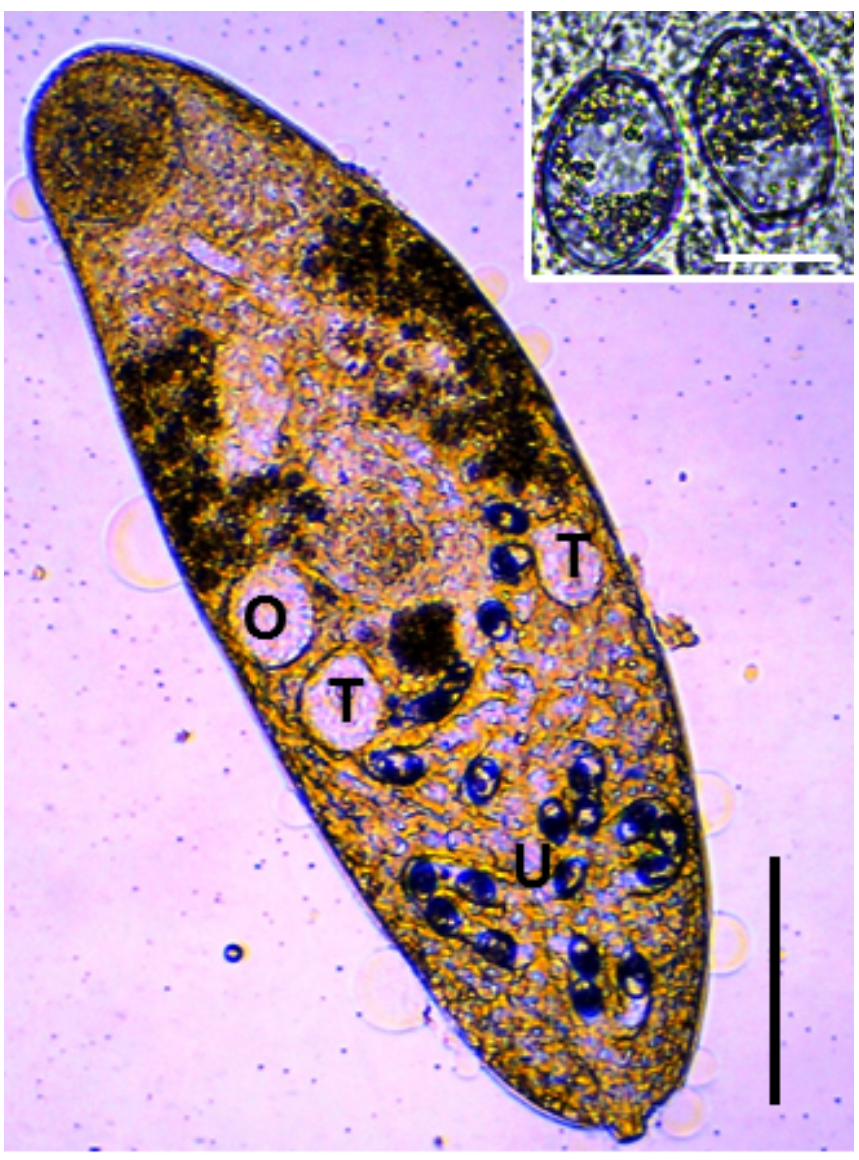

Figure 2. Brachycoelium cf. salamandrae from Eurycea multiplicata, Saline County, Arkansas. Note uterus (U) with ova; scale bar $=200 \mu \mathrm{m}$. Abbreviations: $\mathrm{O}$ (ovary); T (testes). Inset: two ova; scale bar $=25 \mu \mathrm{m}$.

\section{Gorgoderidae}

Phyllodistomum solidum Rankin, 1937. -Two (3\%) E. tynerensis from $3 \mathrm{~km} \mathrm{~S}$ of Mull off Ramblewood Trail, Searcy County $\left(36.059975^{\circ} \mathrm{N}\right.$, $\left.92.59847^{\circ} \mathrm{W}\right)$ were infected with three and one $P$. solidum, respectively. Interestingly, the specimens (USNPC 108057) came from the intestinal tract of these salamanders, not the urinary bladder. This digenean has been previously reported from northern dusky salamander, Desmognathus fuscus from Illinois (Dyer 1986), New York (Goodchild 1943 [experimental infection]), North Carolina (Rankin 1937a, b) and Ohio (Groves 1945) and northern twolined salamander, Eurycea bislineata from Ohio (Groves 1945). The life cycle involves fingernail clams (Pisidium sp.) as first intermediate hosts and dragonfly nymphs as second intermediate hosts
(Goodchild 1943). Thus, we document a new host and a significant new geographic record for $P$. solidum.

Gorgoderina tenua Rankin, 1937 - Seven E. tynerensis (42.9 $\pm 3.3,36-46 \mathrm{~mm} \mathrm{SVL}$ ) from $3 \mathrm{~km} \mathrm{~S}$ of Mull off Ramblewood Trail, Searcy County $\left(36.059975^{\circ} \mathrm{N}, 92.59847^{\circ} \mathrm{W}\right)$ were infected with one to four (mean intensity $=1.4 \pm 1.1$ ) G. tenua. Rankin (1937a) described $G$. tепиa from three-lined salamander (Eurycea guttolineata) from North Carolina. There are currently at least 52 recognized species of Gorgoderina Looss, 1902 with five from North American salamanders (Ambystoma, Eurycea, Desmognathus, Pseudotriton, Necturus, Notophthalamus spp.) (Mata-López et al. 2005). Rosen and Manis (1976) reported Gorgoderina attenuata (Stafford, 1902) Stafford 1905 and Gorgoderina schistorchis Steelman, 1938 from American bullfrog (Lithobates catesbeianus) and Red River mudpuppy (Necturus maculosus louisianensis) from Arkansas, respectively. This is only the second report of $G$. tenua since the original description and we document a new host and geographic record. Molecular analysis of the ITS2/28S region is ongoing (T.J. Fayton, pers. comm.).

\section{Cyclophyllidea}

\section{CESTOIDEA}

Two E. tynerensis (3\%) from Panther Creek at Mull, Marion County $\left(36.082643^{\circ} \mathrm{N}, 92.594726^{\circ} \mathrm{W}\right)$ harbored unknown cyclophyllidean tapeworm cysticerci in the mesenteries. Cysticerci were spheroidal to ovoidal and possessed calcareous corpuscles (USNPC 107940, Fig. 3). This is the first time cyclophyllidean tapeworm cysticerci have been reported from this salamander.
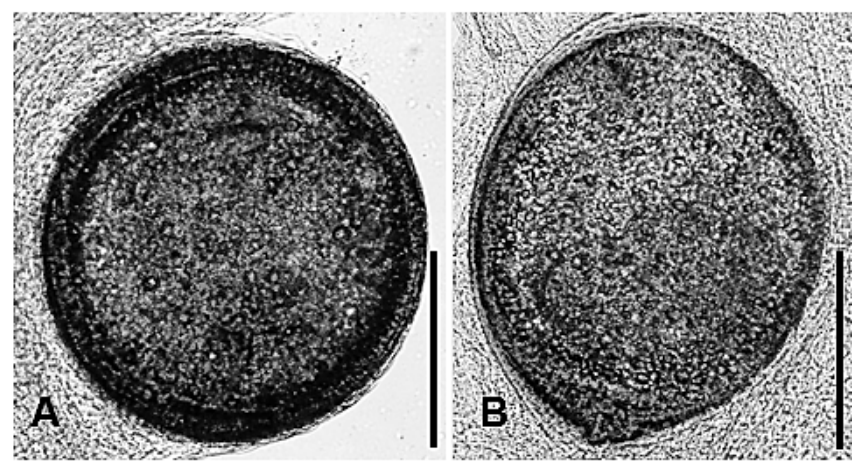

Figure 3. Unknown tapeworm cysticerci from Eurycea tynerensis, Marion County, Arkansas. (A) Spheroidal shape (B) Ovoidal shape. Scale bars $=25 \mu \mathrm{m}$. 


\section{Cyclophyllidea: Cylindrotaeniidae}

Cylindrotaenia americana Jewell, 1916. - One (2\%) E. tynerensis (40 mm SVL) from a spring seep S of Oark off St. Hwy. 103, Johnson County $\left(35.5929^{\circ} \mathrm{N}\right.$, $\left.93.584011^{\circ} \mathrm{W}\right)$ had nine immature cyclophyllidean tapeworms (USNPC 107961) in the small intestine that match the description of $C$. americana (Jewell 1916). Previous hosts from Arkansas include Ouachita dusky salamander, Desmognathus brimleyorum, western slimy salamander, Plethodon albagula, Ozark zig-zag salamander, Plethodon angusticlavius and bird-voiced treefrog, Hyla avivoca (see McAllister et al. 2013c). There are many other amphibian hosts of $C$. americana and its geographic range stretches north to south from Alberta, Canada to Uruguay, including 18 U.S. states, two provinces of Canada, Trinidad, Costa Rica, Mexico, and seven South American countries (see McAllister et al. 2013c). We document a new host record and the first report of this tapeworm in salamanders of the genus Eurycea.

\section{Pseudophyllidea: Bothriocephalidae}

Bothriocephalus rarus Thomas, 1937. - Two (2\%) E. multiplicata $(37,38 \mathrm{~mm}$ SVL) collected from Shannon Hills, Saline County $\left(34.60996^{\circ} \mathrm{N}\right.$, $\left.92.43227^{\circ} \mathrm{W}\right)$ each harbored one worm, and six $(4 \%)$ E. tynerensis, one (30 mm SVL) from Spavinaw Creek, Benton County $\left(36.353059^{\circ} \mathrm{N}, 94.552347^{\circ} \mathrm{W}\right)$ and five $(35.1 \pm 4.5,29-45 \mathrm{~mm} \mathrm{SVL})$ from $3 \mathrm{~km} \mathrm{~S}$ of Mull, Searcy County $\left(36.059975^{\circ} \mathrm{N}, 92.59847^{\circ} \mathrm{W}\right)$ were infected with $B$. rarus (USNPC 107958, 107960) (Fig. 4 ) in their small intestines. Intensity of infection was $1.5 \pm 0.9,1-3$ worms. This tapeworm has been previously reported from the dwarf salamander, Eurycea quadridigitata and dark-sided salamander, Eurycea longicauda melanopleura from Arkansas (McAllister and Bursey 2003, 2004) as well as several other salamanders from California, Kentucky, Michigan, Missouri, New Hampshire, Ohio, Pennsylvania, Tennessee, and West Virginia (see McAllister et al. 2013b). We document two new host records for B. rarus.

\section{Seuratoidea: Quimperiidae \\ NEMATODA}

Desmognathinema nantahalaensis Baker, Goater, and Esch, 1987. - Eight (12\%) E. tynerensis (39.2 \pm 5.6, range $28-47 \mathrm{~mm} \mathrm{SVL})$ harbored a total of 17 (mean intensity $=2.2 \pm 1.9$, range 1-6) $D$. nantahalaensis (USNPC 107937, 107941) in their small intestines. One salamander came from S of Oark off St. Hwy. 103, Johnson County $\left(35.5929^{\circ} \mathrm{N}\right.$, $\left.93.584011^{\circ} \mathrm{W}\right)$, one was collected from $3.2 \mathrm{~km} \mathrm{~S}$ of Cass off St. Hwy. 23, Franklin County $\left(35.646329^{\circ} \mathrm{N}\right.$, $93.839612^{\circ} \mathrm{W}$ ), one came from a wellhouse off St. Hwy. $59 \mathrm{~N}$ of Gentry, Benton County $\left(36.299061^{\circ} \mathrm{N}\right.$, $94.450533^{\circ} \mathrm{W}$ ), three were collected from Panther Creek at Mull, Marion County $\left(36.082643^{\circ} \mathrm{N}\right.$, $92.594726^{\circ} \mathrm{W}$ ) and two were taken $3 \mathrm{~km} \mathrm{~S}$ Mull, Searcy County $\left(36.059975^{\circ} \mathrm{N}, 92.59847^{\circ} \mathrm{W}\right)$. The Oklahoma salamander (as E. m. griseogaster) and cave salamander, Eurycea lucifuga from Arkansas have previously been reported as hosts of this nematode (McAllister and Bursey 2004, McAllister et al. 1995a). In addition, E. multiplicata from Oklahoma is a host (McAllister and Bursey 2010) as well as Desmognathus quadramaculatus (type host) and Desmognathus monticula from North Carolina (Baker et al. 1987). Interestingly, the disjunct range of $D$. nanthalaensis includes only three states, Arkansas, North Carolina, and Oklahoma.

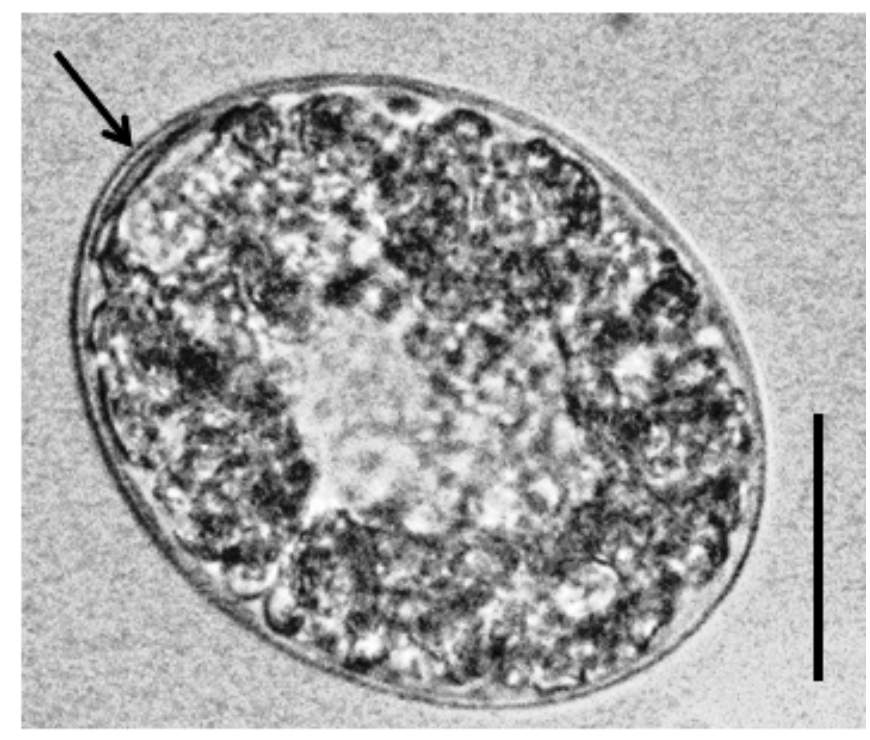

Figure 4. Ovum of Bothriocephalus rarus from Eurycea multiplicata, Saline County, Arkansas. Note operculum (arrow). Scale bar $=50 \mu \mathrm{m}$.

Omeia papillocauda Rankin, 1937. - Two (2\%) E. multiplicata were infected, a single ( $35 \mathrm{~mm}$ SVL) specimen from Tanyard Springs, Conway County $\left(35.115908^{\circ} \mathrm{N}, 92.916619^{\circ} \mathrm{W}\right)$ had one larval worm and one (32 mm SVL) salamander from $4 \mathrm{~km} \mathrm{NW}$ of Caddo Valley and $1 \mathrm{~km} \mathrm{~W}$ of St. Hwy. 7, Clark County $\left(34.215204^{\circ} \mathrm{N}, 93.095655^{\circ} \mathrm{W}\right)$ had one larval and two male O. papillocauda. In addition, $10(7 \%) E$. tynerensis, three (41-43 mm SVL) from Panther Creek at Mull, Marion County $\left(36.082643^{\circ} \mathrm{N}, 92.594726^{\circ} \mathrm{W}\right)$ and seven $(40.6 \pm 7.2,34-52 \mathrm{~mm} \mathrm{SVL})$ from $3 \mathrm{~km} \mathrm{~S}$ 
Mull, Searcy County $\left(36.059975^{\circ} \mathrm{N}, 92.59847^{\circ} \mathrm{W}\right)$ possessed a total of $26(2.6 \pm 3,1,1-11) O$. papillocauda (Fig. 5, USNPC 107938) in their stomachs. Many-ribbed salamanders from Arkansas have been previously reported as hosts of $O$. papillocauda (McAllister and Bursey 2010). It has also been reported from $D$. brimleyorum (McAllister et al. 1995d) and D. monticola from Arkansas (Connior et al. 2013). This nematode has also been reported from several other members of the genus Eurycea as well as Desmognathus and Gyrinophilus from Alabama, North Carolina, Ohio, and Tennessee (see McAllister and Bursey 2010). We document a new host record for $O$. papillocauda in E. tynerensis.

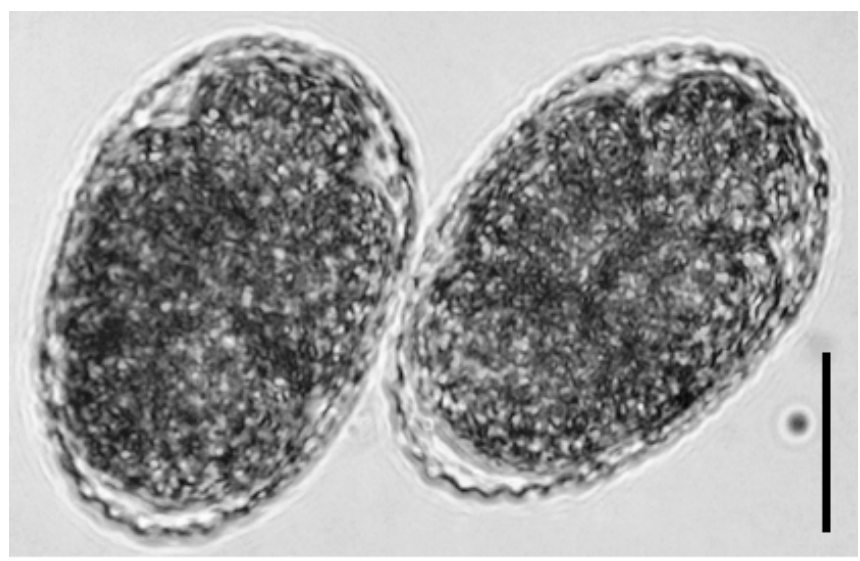

Figure 5. Embryonated ova of Omeia papillocauda from Eurycea tynerensis, Marion County, Arkansas. Note outer rugose shell. Scale bar $=25 \mu \mathrm{m}$.

\section{Oxyurida: Pharyngodonidae}

Batracholandros magnavulvaris (Rankin, 1937) Petter and Quentin, 1976. - Two (2\%) E. multiplicata (43, $45 \mathrm{~mm}$ SVL) from Petit Jean State Park, Conway County $\left(35.114642^{\circ} \mathrm{N}, 92.943574^{\circ} \mathrm{W}\right)$ each harbored one female pinworm (USNPC 107942) in its rectum. In addition, a single (3\%) E. tynerensis (30 mm SVL) from Spavinaw Creek, Benton County $\left(36.353059^{\circ} \mathrm{N}\right.$, $94.552347^{\circ} \mathrm{W}$ ) had three female B. magnavulvaris (USNPC 107959) in the rectum. McAllister et al. (2013c) recently summarized records of $B$. magnavulvaris in caudate amphibians, including seven species of salamanders from Arkansas. There are four other members of the genus Eurycea reported as hosts of this oxyurid from Alabama, Michigan, North Carolina and Tennessee (see McAllister et al. 2013c). The many-ribbed and Oklahoma salamander are new hosts of B. magnavulvaris, which exhibits a direct life cycle (Anderson 2000).

\section{Enoplida: Capillaridae}

Amphibiocapillaria tritonispunctati (Diesing, 1851) Moravec, 1982. - Two (1\%) E. tynerensis, one (43 mm SVL) from Lake Leatherwood, Carroll County $\left(36.442033^{\circ} \mathrm{N}, 93.756562^{\circ} \mathrm{W}\right)$ and the other $(30 \mathrm{~mm}$ larvae) from Savoy Cave, Washington County $\left(36.109846^{\circ} \mathrm{N}, 94.340588^{\circ} \mathrm{W}\right)$ possessed six and one $A$. tritonispunctati (USNPC 107936) in their small intestine (Fig. 6). This nematode was previously reported from Arkansas in E. spelaea (McAllister et al. 2006) and $P$. angusticlavius (McAllister et al. 2013c). In addition, McAllister et al. (2013c) provided a summation of records of $A$. tritonispunctati in Nearctic and Palearctic amphibians of the world; only two members of the genus Eurycea have been previously reported as hosts of this worm and we add one more.

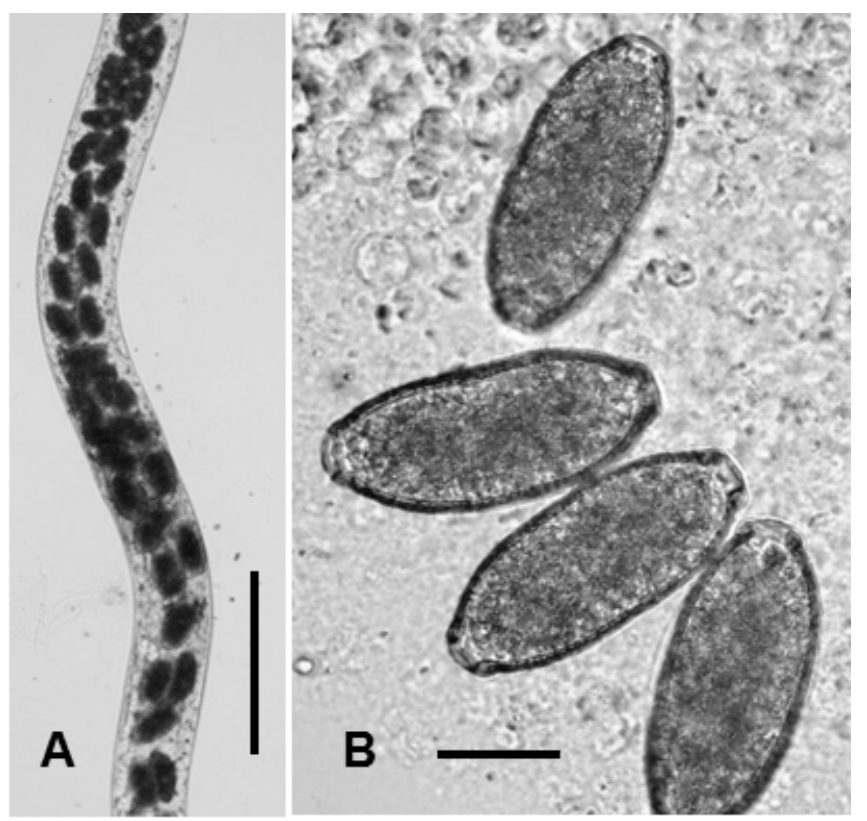

Figure 6. Amphibiocapillaria tritonispunctati from Eurycea tynerensis, Carroll County, Arkansas. (A) Gravid female showing numerous ova; scale bar $=100 \mu \mathrm{m}$. (B) Higher magnification of four individual ova from same showing typical capillariid morphology; scale bar $=25 \mu \mathrm{m}$.

\section{Ascarida: Cosmocercidae}

Cosmocercoides variabilis (Harwood, 1930) Travassos, 1931. - Two (2\%) E. multiplicata (34, 37 $\mathrm{mm}$ SVL) from Shannon Hills, Saline County $\left(34.60996^{\circ} \mathrm{N}, 92.43227^{\circ} \mathrm{W}\right)$ harbored one female and two male $C$. variabilis (USNPC 107939) in the large intestine, respectively. Previously, only female Cosmocercoides sp. was reported from this same host species and same population by McAllister and Bursey (2010); since only females were found it was not possible to assign their specimens to species. In 
Journal of the Arkansas A cademy of Science, V ol. 68 [2014], Art. 15

Arkansas, C. variabilis has been reported from ringed salamander, Ambystoma annulatum, E. $l$. melanopleura, E. lucifuga, Caddo Mountain salamander, Plethodon caddoensis, Rich Mountain salamander, Plethodon ouachitae, pickerel frog, Lithobates palustris and Cajun chorus frog, Pseudacris fouquettei (see McAllister et al. 2013a). Nematodes of this genus/species are common in both amphibians and reptiles and its range includes at least 24 U.S. states, four provinces of Canada, Mexico, Costa Rica and Panama (summarized by Bursey et al. 2012, McAllister et al. 2013d). We document a new host record for $C$. variabilis.

\section{ACANTHOCEPHALA \\ Oligacanthorhynchidae (cystacanth)}

An unknown oligacanthorhynchid cystacanth (USNPC 107944) was found in one $(1 \%) E$. multiplicata (39 mm SVL) from Petit Jean State Park, Conway County $\left(35.114642^{\circ} \mathrm{N}, 92.943574^{\circ} \mathrm{W}\right)$. There is only one previous report of this parasite from an Arkansas salamander, the western slimy salamander, Plethodon albagula (McAllister et al. 1993). Juvenile stages of oligacanthorhynchid acanthocephalans have been found in other amphibians (Moore 1946, McAlpine 1996), reptiles (Elkins and Nickol 1983) and mammals (Radomski 1991). However, Elkins and Nickol (1983) and Bolette (1997) consider reptiles in these instances to be paratenic hosts and we believe salamanders are accidental or transport hosts acting as a trophic bridge between intermediate and definitive hosts. For those acanthocephalans parasitic in terrestrial animals, the intermediate hosts are usually insects (Nickol 1985). Salamanders are known to eat insects (Trauth et al. 2004) and thus, might be expected to become infected. We document a new host record.

\section{Echinorhynchida: Fessisentidae}

Fessisentis vancleavei (Hughes and Moore, 1943) Nickol, 1972 - Six (4\%) E. tynerensis (47.3 \pm 5.9, 40$55 \mathrm{~mm} \mathrm{SVL}$ ), one collected from S of Oark off St. Hwy. 103, Johnson County $\left(35.5929^{\circ} \mathrm{N}\right.$, $93.584011^{\circ} \mathrm{W}$ ), another from $3.2 \mathrm{~km} \mathrm{~S}$ of Cass off St. Hwy. 23, Franklin County $\left(35.646329^{\circ} \mathrm{N}\right.$, $\left.93.839612^{\circ} \mathrm{W}\right)$ and four from JFK Park, Little Red River, Cleburne County $\left(35.512919^{\circ} \mathrm{N}, 91.997125^{\circ} \mathrm{W}\right)$ was found to harbor a total of $18(3.1 \pm 2.4,1-7) F$. vancleavei (USNPC 107962). In addition, one of two $(50 \%$ [overall prevalence $=1 \%$ ]) larval E. multiplicata (30 mm SVL) from Beavers Bend State Park off St. Hwy. 259A, McCurtain County, Oklahoma $\left(34.113292^{\circ} \mathrm{N}, \quad 94.708729^{\circ} \mathrm{W}\right)$ had a single acanthocephalan (USNPC 107943). Fessisentis vancleavei has been previously reported from $E$. tynerensis in Arkansas (Buckner and Nickol 1978, McAllister et al. 1995b) and Oklahoma (Hughes and Moore 1943a, Malewitz 1956). The life cycle of Fessientis spp. involves aquatic isopods as intermediate hosts (Buckner and Nickol 1979). Eurycea multiplicata is a new host of $F$. vancleavei.

This paper represents the second report of endoparasites of E. multiplicata and only the second thorough survey of E. tynerensis for helminths. We document 13 new host records for E. multiplicata and $E$. tynerensis and new distributional records for $P$. solidum and G. tenua. As noted by McAllister and Bursey (2010), the number of parasite species in $E$. multiplicata should increase with further study, and they did here by $50 \%$, from three to six with our additional survey. Where comparisons are made, helminths shared by both salamanders include a trematode (B. salamandrae), a tapeworm (B. rarus), three nematodes (B. magnavulvaris, D. nantahalaensis, $O$. papillocauda) and an acanthocephalan ( $F$. vancleavei), with most exhibiting prevalences $<5 \%$ (Table 1). Therefore, studies on these salamanders lend support to Aho's (1990) contention that caudate species are among the most depauperate hosts of all vertebrates. We suggest that future studies should include a larger sample size of $E$. multiplicata and $E$. tynerensis from a variety of localities in Oklahoma. In addition, if samples of the recently described and related Ouachita streambed salamander, Eurycea subfluvicola (Steffen et al. 2014) from Arkansas become available for study, it will be interesting to see if its helminth parasites are shared with E. multiplicata and E. tynerensis, particularly in areas of sympatry with the former.

\section{Acknowledgments}

We thank the Arkansas Game \& Fish Commission, USDA Forest Service (Ozark and Ouachita Districts) and Oklahoma Department of Wildlife Conservation for Scientific Collecting permits issued to CTM and MBC. We also appreciate the expert curatorial assistance of P. A. Pilitt (USNPC) and Dr. S. E. Trauth (ASUMZ). We further acknowledge Sammy and Wendy Stuart for allowing CTM to collect on their properties in Saline County and T.J. Fayton (Gulf Coast Research Lab, Univ. S. Mississippi) and Dr. V.V. Tkach (Univ. North Dakota) for future DNA sequencing of select trematodes from these hosts. Nikolas H. and Rachel A. McAllister aided in collecting. 
Table 1. Summary of helminth parasites of Eurycea multiplicata and Eurycea tynerensis.

\begin{tabular}{llll}
\hline Helminth & State Prevalence* & Refence
\end{tabular}

\section{Trematoda}

Brachycoelium cf. salamandrae $\dagger$

\section{Cestoidea}

Bothriocephalus rarus $\dagger$

\section{Nematoda}

Batracholandros magnavulvaris $\dagger$

Cosmocercoides sp. $\$$

Cosmocercoides variabilis $\dagger$

Desmognathinema nantahalaensis

Omeia papillocauda

\section{Acanthocephala}

Fessisentis vancleavei†

Oligacanthorhynchid cystacanth $\dagger$

\section{Trematoda}

Brachycoelium cf. salamandrae

Clinostomum marginatum

Phyllodistomum solidum $\dagger$

Gorgoderina tenua $\dagger$

Sphyranura euryceae

\section{Cestoidea}

Bothriocephalus rarus $\dagger$

Cylindrotaenia americana $\dagger$

Unknown cysticerci

\section{Nematoda}

Amphibiocapillaria tritonipunctati $\dagger$

Batracholandros magnavulvaris $\dagger$

Desmognathinema nantahalaensis

Omeia papillocauda $\dagger$

\section{Acanthocephala}

Fessisentis vancleavei

\section{Eurycea multiplicata}

Arkansas $\quad 2 / 88(2 \%) \quad$ This study

Arkansas $\quad 2 / 88(2 \%) \quad$ This study

$\begin{array}{lll}\text { Arkansas } & 2 / 88(2 \%) & \text { This study } \\ \text { Arkansas } & 3 / 61(5 \%) & \text { McAllister and Bursey (2010) } \\ \text { Arkansas } & 2 / 88(2 \%) & \text { This study } \\ \text { Oklahoma } & 3 / 5(60 \%) & \text { McAllister and Bursey (2010) } \\ \text { Arkansas } & 1 / 61(2 \%) & \text { McAllister and Bursey (2010) } \\ & 2 / 88(2 \%) & \text { This study } \\ & & \text { This study } \\ \text { Oklahoma } & 1 / 2(50 \%) & \text { This study } \\ \text { Arkansas } & 1 / 88(1 \%) & \end{array}$

Eurycea tynerensis

$\begin{array}{ll}\text { Arkansas } & 1 / 50(2 \%) \\ \text { Oklahoma } & 9 / 74(12 \%) \\ \text { Arkansas\| } & 2 / 135(1 \%) \\ \text { Arkansas\| } & 7 / 135(5 \%) \\ \text { Arkansas } & 10 / 10(100 \%) \\ & 37 / 74(50 \%) \\ \text { Oklahoma } & 45 / 90(50 \%)\end{array}$

McAllister et al. (1995)

Bonett et al. (2011)

This study

This study

McAllister et al. (1991)

McAllister et al. (2011)

Moore and Hughes (1943b)

$\begin{array}{lll}\text { Arkansas } & 2 / 135(1 \%) & \text { This study } \\ \text { Arkansas } & 1 / 135(0.7 \%) & \text { This study } \\ \text { Arkansas } & 3 / 50(6 \%) & \text { McAllister et al. (1995) } \\ & 8 / 135(6 \%) & \text { This study } \\ \text { Arkansas } & 10 / 135(7 \%) & \text { This study }\end{array}$

$\begin{array}{lll}\text { Arkansas } & \text { not given } & \text { Buckner and Nickol (1978) } \\ & 2 / 50(4 \%) & \text { McAllister et al. (1995) } \\ & 6 / 135(4 \%) & \text { This study } \\ \text { Oklahoma } & 10 / 73(14 \%) & \text { Moore and Hughes (1943a) } \\ & 8 / 19(42 \%) & \text { Malewitz (1956) }\end{array}$

*Prevalence $=$ number infected/number examined $(\%)$. $\uparrow$ New host record. $\ddagger$ Only females; specific identity not possible. $\|$ New distributional record. 
Journal of the Arkansas A cademy of Science, Vol. 68 [2014], Art. 15

C.T. McAllister, M.B. Connior, C.R. Bursey and H.W. Robison

\section{Literature Cited}

Aho JM. 1990. Helminth communities of amphibian and reptiles: Comparative approaches to understanding patterns and processes. In Esch GW, AO Bush and JM Aho, editors. Parasite Communities: Pattern and Processes. London (UK): Chapman and Hall. p 157-195.

Anderson RC. 2000. Nematode parasites of vertebrates: Their development and transmission, $2^{\text {nd }}$ ed. Wallingford, Oxon (UK): CAB International. $650 \mathrm{p}$.

Baker MR, TM Goater and GW Esch. 1987. Descriptions of three nematode parasites of salamanders (Plethodontidae: Desmognathinae) from the southeastern United States. Proceedings of the Helminthological Society of Washington 54:15-23.

Bolette DP. 1997. Oligacanthorhynchid cystacanths (Acanthocephala) in a long-nosed snake, Rhinochelius lecontei lecontei (Colubridae) and a Mojave rattlesnake Crotalus scutulatus scutulatus (Viperidae) from Maricopa County, Arizona. Southwestern Naturalist 42:232-236.

Bonett RM. 2005. Eurycea tynerensis Moore and Hughes, 1939, Oklahoma salamander. In Lannoo, M, editor. Amphibian declines: the conservation status of United States species. Berkeley (CA): University of California Press. p 767-769.

Bonett RM and PT Chippindale. 2004. Speciation, phylogeography and evolution of life history and morphology in plethodontid salamanders of the Eurycea multiplicata complex. Molecular Ecology 13:1189-1203.

Bonett RM and PT Chippindale. 2006. Streambed microstructure predicts evolution of development and life history mode in the plethodontid salamander Eurycea tynerensis. BMC Biology 4:6

Bonett RM, MA Steffen, AL Trujano-Alvarez, SD Martin, CR Bursey and CT McAllister. 2011. Distribution, abundance, and genetic diversity of Clinostomum spp. metacercariae (Trematoda: Digenea) in a modified Ozark stream system. Journal of Parasitology 97:177-184.

Buckner RL and BB Nickol. 1978. Redescription of Fessisentis vancleavei (Hughes and Moore, 1943) Nickol, 1972 (Acanthocephala: Fessisentidae). Journal of Parasitology 64:635-637.
Buckner RL and BB Nickol. 1978. Geographic and host-related variation among species of Fessisentis (Acanthocephala) and confirmation of the Fessisentis fessus life cycle. Journal of Parasitology 65:161-166.

Bursey CR, SR Goldberg, SR Telford, Jr and LJ Vitt. 2012. Metazoan endoparasites of 13 species of Central American anoles (Sauria: Polycrotidae: Anolis) with a review of the helminth communities of Carribean, Mexican, North American, and South American anoles. Comparative Parasitology 79:75-132.

Bush AO, KD Lafferty, JM Lotz and AW Shostak. 1997. Parasitology meets ecology on its own terms: Margolis et al. revisited. Journal of Parasitology 83:575-583.

Cline GR and R Tumlison. 1997. Further notes on the habitat of the Oklahoma salamander (Eurycea tynerensis). Proceedings of the Oklahoma Academy of Science 77:103-106.

Cline GR and R Tumlison. 2001. Distribution and relative abundance of the Oklahoma salamander (Eurycea tynerensis). Proceedings of the Oklahoma Academy of Science 81:1-10.

Cline GR, R Tumlison and P Zwank. 1989. Biology and ecology of the Oklahoma salamander, Eurycea tynerensis: Literature review and comments on research needs. Bulletin of the Chicago Herpetological Society 24:164-168.

Connior MB, CT McAllister, HW Robison and CR Bursey. 2013. Status of an exotic salamander, Desmognathus monticola (Caudata: Plethodontidae), and discovery of an introduced population of Cottus immaculatus (Perciformes: Cottidae) in Arkansas. Journal of the Arkansas Academy of Science 66:165-168.

Connior MB, R Tumlison, HW Robison and CT McAllister. 2014. Natural history notes and records of vertebrates from Arkansas. Journal of the Arkansas Academy of Science 68:140-145.

Dundee HA. 1965. Eurycea multiplicata. In Reimer, WJ, editor. Catalogue of American Amphibians and Reptiles. New York: Society for the Study of Amphibians and Reptiles. p. 21.1-21.2.

Dyer WG. 1986. First record of Phyllodistomum solidum Rankin 1937 (Trematoda: Gorgoderidae) in the dusky salamander (Desmognathus fuscus) from southern Illinois. Transactions of the Illinois Academy of Science 79:291-292. 
Elkins CA and BB Nickol. 1983. The epizootiology of Macracanthorhynchus ingens in Louisiana. Journal of Parasitology 69:951-956.

Emel SL and RM Bonett. 2011. Considering alternative life history modes and genetic divergence in conservation: A case study of the Oklahoma salamander. Conservation Genetics 12:1243-1259.

Goodchild CG. 1943. The life-history of Phyllodistomum solidum Rankin, 1937, with observations on the morphology and development and taxonomy of the Gorgoderinae (Trematoda). Biological Bulletin 84:59-86.

Groves RE. 1945. An ecological study of Phyllodistomum sodium Rankin, 1937 (Trematoda: Gordoderidae). Transactions of the American Microscopical Society 64:112-132.

Hughes RC and GA Moore. 1943a. Acanthocephalus van-cleavei, a new echinorhynchid worm, from a salamander. American Midland Naturalist 29:724729.

Hughes RC and GA Moore. 1943b. Sphyranura euryceae, a new polystomatid monogenean fluke from Eurycea tynerensis. Transactions of the American Microscopical Society 62:286-292.

Ireland PH. 1976. Reproduction and larval development in the gray-belly salamander, Eurycea multiplicata griseogaster. Herpetologica 32:233-238.

Jewell ME. 1916. Cylindrotaenia americana nov. spec. from the cricket frog. Journal of Parasitology 2:181193.

Malewitz TD. 1956. Intestinal parasitism of some midwestern salamanders. American Midland Naturalist 55:434-436.

Martin SD, BA Harris, JR Collums and RM Bonett. 2012. Life between predators and a small space: Substrate selection of an interstitial space-dwelling stream salamander. Journal of Zoology 287:205-214.

Mata-López R, V León-Règagnon and DR Brooks. 2005. Species of Gorgoderina (Digenea: Gorgoderidae) in Rana vaillanti and Rana cf. forreri (Anura: Ranidae) from Guanacaste, Costa Rica, including a description of a new species. Journal of Parasitology 91:403-410.

McAllister CT and CR Bursey. 2003. Bothriocephalus rarus (Cestoidea: Pseudophyllidea) from the dwarf salamander, Eurycea quadridigitata (Amphibia: Caudata), in southern Arkansas, with a review of this tapeworm species in other salamander hosts. Texas Journal of Science 55:277-281.
McAllister CT and CR Bursey. 2004. Endoparasites of the dark-sided salamander, Eurycea longicauda melanopleura, and the cave salamander, Eurycea lucifuga (Caudata: Plethodontidae), from two caves in Arkansas, U.S.A. Comparative Parasitology 71:61-66.

McAllister CT and CR Bursey. 2010. Nematode parasites of the many-ribbed salamander, Eurycea multiplicata (Caudata: Plethodontidae), from Arkansas and Oklahoma. Proceedings of the Oklahoma Academy of Science 90:69-73.

McAllister CT, CR Bursey, MB Connior, LA Durden and HW Robison. 2014. Helminth and arthropod parasites of the ground skink, Scincella lateralis (Sauria: Scincidae), from Arkansas and Oklahoma, U.S.A. Comparative Parasitology 81:210-219.

McAllister CT, CR Bursey, MB Connior and SE Trauth. 2013a. Symbiotic Protozoa and helminth parasites of the Cajun chorus frog, Pseudacris fouquettei (Anura: Hylidae), from southern Arkansas and northeastern Texas, U.S.A. Comparative Parasitology 80:96-104.

McAllister CT, CR Bursey, D Fenolio and ML Niemiller. 2013b. Bothriocephalus sp. (Cestoidea: Bothriocephalidae) from the Georgia blind salamander, Eurycea wallacei (Caudata: Plethodontidae), in Georgia, U.S.A.: First definitive report of a parasite from this host. Comparative Parasitology 80:308-311.

McAllister CT, CR Bursey, HW Robison and MB Connior. 2013c. Endoparasites of the spotted dusky dusky salamander, Desmognathus conanti (Caudata: Plethodontidae), from southern Arkansas, U.S.A. Comparative Parasitology 80:6068.

McAllister CT, CR Bursey, HW Robison and MB Connior. 2013d. Parasites of the Ozark zigzag salamander, Plethodon angusticlavius (Caudata: Plethodontidae), from northern Arkansas. Comparative Parasitology 80:69-79.

McAllister CT, CR Bursey, MA Steffen, SE Martin, AL Trujano-Alvarez and RM Bonett. 2011. Sphyranura euryceae (Monogenoidea: Polystomatonoinea: Sphyranuridae) from the grotto salamander, Eurycea spelaea and Oklahoma salamander, Eurycea tynerensis (Caudata: Plethodontidae), in northeastern Oklahoma, USA. Comparative Parasitology 78:188-192. 
McAllister CT, CR Bursey, SE Trauth, and D Fenolio. 2006. Helminth parasites of the grotto salamander, Eurycea spelaea (Caudata: Plethodontidae), from northern Arkansas and southern Missouri, U.S.A. Comparative Parasitology 73:291-297.

McAllister CT, CR Bursey, SJ Upton, SE Trauth, and DB Conn. 1995a. Parasites of Desmognathus brimleyorum (Caudata: Plethodontidae) from the Ouachita Mountains of Arkansas and Oklahoma. Journal of the Helminthological Society of Washington 62:150-156.

McAllister CT, SE Trauth and CR Bursey. $1995 \mathrm{~b}$. Metazoan parasites of the graybelly salamander, Eurycea multiplicata griseogaster (Caudata: Plethodontidae), from Arkansas. Journal of the Helminthological Society of Washington 62:66-69.

McAllister CT, SE Trauth and LW Hinck. 1991. Sphyranura euryceae (Monogenea) on Eurycea spp. (Amphibia: Caudata), from northcentral Arkansas. Journal of the Helminthological Society of Washington 58:137-140.

McAllister CT, SJ Upton and SE Trauth. 1993. Endoparasites of western slimy salamanders, Plethodon albagula (Caudata: Plethodontidae), from Arkansas. Journal of the Helminthological Society of Washington 60:124-126.

McAlpine DE. 1996. Acanthocephala parasitic in North American amphibians: A review with new records. Alytes 14:115-121.

Moore DV. 1946. Studies on the life history and development of Macracanthorhynchus ingens Meyer, 1933, with a redescription of the adult worm. Journal of Parasitology 32:387-399.

Nickol BB. 1985. Epizootiology. In Crompton D.W.T. and B. B. Nickol, editors. Biology of the Acanthocephala. Cambridge (UK): Cambridge University Press. p 307-346.

Radomski AA, DA Osborn, DB Pence, MI Nelson and RJ Warren. 1991. Visceral helminths from an expanding insular population of the long-nosed armadillo (Dasypus novemcinctus). Journal of the Helminthological Society of Washington 58:1-6.

Rankin Jr JS. 1937a. New helminths from North Carolina salamanders. Journal of Parasitology 23:29-42.

Rankin Jr JS. 1937b. An ecological study of parasites of some North Carolina salamanders. Ecological Monographs 7:169-269.

Rosen R and R Manis. 1976. Trematodes of Arkansas amphibians. Journal of Parasitology 62:833-834.
Sievert G and L Sievert. 2011. A field guide to Oklahoma's amphibians and reptiles. Oklahoma City (OK): Oklahoma Department of Wildlife Conservation. $211 \mathrm{p}$.

Steffen MA, KJ Irwin, AL Blair and RM Bonett. 2014. Larval masquerade: A new species of paedomorphic salamander (Caudata: Plethodontidae: Eurycea) from the Ouachita Mountains of Arkansas. Zootaxa 3786:423-442.

Trauth SE and HA Dundee. 2005. Eurycea multiplicata (Cope, 1869), many-ribbed salamander. In Lannoo, M, editor. Amphibian declines: the conservation status of United States species. Berkeley (CA): University of California Press. p. 753-755.

Trauth SE, HW Robison and MV Plummer. 2004. The amphibians and reptiles of Arkansas. Fayetteville (AR): University of Arkansas Press. $421 \mathrm{p}$.

Tumlison R and RG Cline. 2003. Association between the Oklahoma salamander (Eurycea tynerensis) and Ordovician-Silurian strata. Southwestern Naturalist 48:93-95.

Tumlison R, GC Cline and P Zwank. 1990a. Morphological discrimination between the Oklahoma salamander (Eurycea tynerensis) and the graybelly salamander (Eurycea multiplicata griseogaster). Copeia 1990:242-246.

Tumlison R, GC Cline and P Zwank. 1990b. Surface habitat associations of the Oklahoma salamander (Eurycea tynerensis). Herpetologica 46:169-175. 